Southern Methodist University

SMU Scholar

Faculty Journal Articles and Book Chapters

Faculty Scholarship

2007

\title{
The Corporate/Securities Attorney as a 'Moving Target' - Client Fraud Dilemmas
}

Marc I. Steinberg

Southern Methodist University, Dedman School of Law

\section{Recommended Citation}

Marc I. Steinberg, The Corporate/Securities Attorney as a 'Moving Target' - Client Fraud Dilemmas

This document is brought to you for free and open access by the Faculty Scholarship at SMU Scholar. It has been accepted for inclusion in Faculty Journal Articles and Book Chapters by an authorized administrator of SMU Scholar. For more information, please visit http://digitalrepository.smu.edu. 


\section{SMIIIIDEDMAN \\ School of Law}

\section{The Corporate/Securities Attorney as a "Moving Target" - Client Fraud Dilemmas}

Marc Steinberg, Sr. Associate Dean for Research

\section{SMU Dedman School of Law Legal Studies Research Paper Number 00-02}

This paper can be downloaded without charge from the Social Science Research Network electronic library at: http://ssrn.com/abstract $=967478$ 


\section{The Corporate/Securities Attorney as a "Moving Target" - Client}

\section{Fraud Dilemmas}

\section{Marc I. Steinberg*}

This Paper analyzes the enhanced responsibilities and liability concerns that corporate/securities attorneys have in the post-Enron era. State ethical rules, SEC pronouncements, and court decisions are addressed. The ramifications of the Sarbanes-Oxley Act with respect to its impact on legal counsel also are explored. The Paper also provides insight focusing on the business attorney's role as counselor and gatekeeper when faced with the prospect of client fraud.

\section{Introduction}

When an attorney's client commits fraud or other illegality, the attorney may be held liable as a direct or indirect participant. Such liability may be imposed under the federal or state securities laws or common law. ${ }^{1}$ Not surprisingly, private claimants increasingly are targeting lawyers, at times recovering enormous sums. ${ }^{2}$ In the government enforcement context, the Securities and Exchange Commission (SEC) has stepped-up its enforcement efforts against attorneys, both in-house and outside counsel. ${ }^{3}$ At times, even criminal prosecution may eventuate. ${ }^{4}$ The portrayal of the attorney as "gatekeeper" is now a fixture in the attorney responsibility 
landscape. ${ }^{5}$

This Article focuses on attorney conduct standards when client fraud may be afoot. Attorney ethical standards, the SEC's Rule 102(e) pronouncements, and the Commission's Standards of Conduct as mandated by the Sarbanes-Oxley Act (SOX) are addressed. This Article also explores other key subjects in this context including whether counsel has a duty to "blow the whistle," the controversial "noisy withdrawal" issue, predecessor-successor counsel communications, and responding to auditor requests concerning client contingent liabilities.

\section{Ethical Rules}

Under applicable ethical rules, a lawyer retained by a corporation (or other business organization) represents such entity acting through the entity's authorized constituents (e.g., its board of directors or senior management). ${ }^{6}$ If counsel for a business enterprise knows ${ }^{7}$ that an officer, employee or other individual affiliated with that enterprise is engaged in a violation of law that reasonably might be attributed to the enterprise and that is likely to cause substantial injury to the organization, then counsel shall proceed as is reasonably necessary in the organization's best interest. In fulfilling this directive, counsel "shall refer the matter to higher authority in the organization, including, if warranted by the circumstances, to the highest authority that can act on behalf of the organization as determined by 
applicable law [e.g., the corporation's board of directors]." After the attorney's referral to the board of directors or comparable authority, if the wrongdoers persist in the illegality that is reasonably certain to cause substantial injury to the enterprise, then counsel should resign from the representation. ${ }^{9}$ Moreover, under the vast majority but not all state ethical rules, ${ }^{10}$ counsel may reveal information outside the organization to the extent that such information is necessary to prevent or mitigate the client's fraud or crime. ${ }^{11}$

Two other ethical rules merit identification in this setting. One is that counsel shall not knowingly assist a client in conduct that is fraudulent or criminal. ${ }^{12}$ The second, which may arise in the legal opinion or drafting context, ${ }^{13}$ provides that an attorney may not knowingly "make a false statement of material fact or law to a third person or fail to disclose a material fact when disclosure is necessary to avoid assisting a criminal or fraudulent act by a client, unless disclosure is prohibited by Rule 1.6."14 A number of states base a violation of this ethical mandate on an attorney's negligence. ${ }^{15}$

\section{Duty to "Blow the Whistle"}

The following discussion focuses on an attorney's duty under the federal securities laws to disclose her client's misstatements to third parties. Generally, to establish Securities Exchange Act Section 10(b) ${ }^{16}$ (or other federal securities law) 
liability on the basis of counsel's silence, a duty to disclose must be established. ${ }^{17}$ Several courts have concluded that the federal securities laws are not the source of such a duty. ${ }^{18}$ Further, absent a fiduciary duty between plaintiff and defendant, there is generally no liability for failing to blow the whistle at common law. ${ }^{19}$ Rather, as a general principle, the secondary actor's duty to disclose may arise where a fiduciary or other confidential relationship is found to exist. ${ }^{20}$

Based on counsel's silence, the duty to disclose or "blow the whistle" on one's client thus is unlikely to give rise to securities law liability. ${ }^{21}$ As held by the U.S. Court of Appeals for the Seventh Circuit, lawyers have no independent duty to "blow the whistle." ${ }^{22}$ Elaborating, the court pronounced:

The extent to which lawyers ... should reveal their client's wrongdoing - and to whom they should reveal - is a question of great moment. ... We express no opinion on whether the [law firms] did what they should, whether there was malpractice under state law, or whether the rules of ethics (or other fiduciary doctrines) ought to require lawyers ... to blow the whistle in equivalent circumstances. We are satisfied, however that an award of damages under the securities laws is not the way to blaze the trail toward improved ethical standards in the legal profession. Liability depends on an existing duty to disclose. The securities law therefore must lag behind changes 
in ethical and fiduciary standards. The plaintiffs have not pointed to any rule imposing on either [law firm] a duty to blow the whistle."23

Similar analysis has been employed to insulate legal counsel from such liability under state law. ${ }^{24}$

\section{SEC Action}

\section{A. In General}

SEC actions against attorneys are most often, though not always, ${ }^{25}$ products of SEC administrative,${ }^{26}$ injunctive ${ }^{27}$ or disciplinary proceedings. ${ }^{28}$ In these actions, the Commission has commented on the role that attorneys play in the disclosure process and, at times, has ordered the restructuring of internal procedures of law firms. ${ }^{29}$

For example, in In re Fields, ${ }^{30}$ the Commission asserted that securities lawyers occupy a strategic position in the investment process and that the SEC, with its limited resources, "is peculiarly dependent on the probity and diligence of the professionals who practice before it." ${ }^{, 31}$

With respect to the lack of adequate internal procedures within law firms, the Commission has ordered that these procedures be revised where appropriate. In this context, the SEC has posited that "[a] law firm has a duty to make sure that disclosure documents filed with the Commission include all material facts about a client of which it has knowledge as a result of its legal representation of that client." 32 


\section{B. SEC Rule 102(e)}

The SEC over the past three decades has brought several disciplinary proceedings under Rule 2(e) (now Rule 102(e)) against lawyers and accountants. ${ }^{33}$ Rule 102(e) generally provides that the SEC may temporarily suspend or permanently bar any person from practice before it upon finding such person (1) to lack the requisite qualifications to represent others, (2) to lack character or integrity or to have engaged in improper or unethical professional conduct, or (3) to have willfully violated or aided and abetted a violation of any provision of the federal securities laws or any rule or regulation thereunder. ${ }^{34}$ This rule has been codified in part pursuant to enactment of the Sarbanes-Oxley Act of 2002 (SOX) as an amendment to the Securities Exchange Act. ${ }^{35}$

The SEC's invocation of Rule 102(e) has been extensively criticized. ${ }^{36}$ The Commission has responded that the rule, rather than being an enforcement mechanism, is necessary to preserve the integrity of its own processes. ${ }^{37}$ Prior to the enactment of SOX in 2002 (which codified in part Rule 2(e) (or Rule 102(e)), ${ }^{38}$ the courts, with certain exceptions, ${ }^{39}$ agreed with the SEC. ${ }^{40}$ The most significant decision upholding the Commission's authority under Rule 2(e) is Touche Ross \& Co., v. SEC. ${ }^{41}$ Although that case specifically concerned the discipline of accountants, the language employed by the U.S. Court of Appeals for the Second 
Circuit applies as well to the SEC's disciplinary authority over attorneys. The court reasoned:

The role of the accounting and legal professions in implementing the objectives of the disclosure policy has increased in importance as the number and complexity of securities transactions has increased. By the very nature of its operations, the Commission, with its small staff and limited resources, cannot possibility examine, with the degree of close scrutiny required for full disclosure, each of the many financial statements which are filed. Recognizing this, the Commission necessarily must rely heavily on both the accounting and legal professions to perform their tasks diligently and responsibly. Breaches of professional responsibility jeopardize the achievement of the objectives of the securities laws and can inflict great damage on public investors. As our Court [has] observed ..., "In our complex society the accountants' certificates or the lawyer's opinion can be instruments for inflicting pecuniary loss more potent than a chisel or a crowbar." 42

Thus, the Second Circuit concluded:

To summarize: we reject appellant's assertion that the Commission acted without authority in promulgating Rule 2(e). Although there is no express statutory provision authorizing the Commission to discipline professionals 
appearing before it, Rule 2(e), promulgated pursuant to its statutory rulemaking authority, represents an attempt by the Commission to protect the integrity of its own processes. It provides the Commission with the means to ensure that those professionals, on whom the Commission relies heavily in the performance of its statutory duties, perform their tasks diligently and with a reasonable degree of competence. As such the Rule is "reasonably related" to the purposes of the securities laws. Moreover, we hold that the Rule does not violate, nor is it inconsistent with, any other provision of the securities laws. We therefore sustain the validity of the Rule as a necessary element adjunct to the Commission's power to protect the integrity of its administrative procedures and the public in general. ${ }^{43}$

An important issue that the Second Circuit in Touche Ross raised but left unresolved is whether the Commission has the authority to discipline an entire firm for the misconduct of certain of its members. ${ }^{44}$ In a significant Rule 2(e) proceeding against a law firm, the SEC pointed out that the case involved the firm's failure to maintain adequate internal control mechanisms which would have "assured that the knowledge of the members of the firm was communicated to the persons responsible for preparing disclosure documents so that adequate disclosure of material information - which was within the firm's knowledge - was made." ${ }^{45}$ Moreover, the 
Commission found it appropriate to state that the proceeding was "not [one] where a law firm is being held accountable for knowledge or conduct of a few of its members." ${ }^{46}$

Perhaps the most significant administrative disciplinary proceeding brought against attorneys pursuant to Rule 2(e) is that of In the Matter of Carter and Johnson. ${ }^{47}$ There, the Commission's Office of General Counsel had argued that where a lawyer's advice has been repeatedly rejected by management and where management persists in exposing the corporation to substantial risk of legal liability, the lawyer may have an obligation to go up the hierarchal structure within the corporation to the board of directors in order to prevent what the lawyer believes to be present or future violations of the law. The General Counsel argued that this duty to go to the board may be necessary in order to fulfill the lawyer's obligation adequately to advise the corporate client. ${ }^{48}$

In 1982, the Williams Commission handed down its opinion in the CarterJohnson case. ${ }^{49}$ It reversed the decision of the administrative law judge, who had found that Carter and Johnson, lawyers who were experienced in corporate and securities matters, had violated the federal securities laws and had engaged in improper professional conduct..$^{50}$

The Commission dismissed the proceeding against the two lawyers. While 
asserting once again its jurisdiction to conduct these kinds of proceedings, ${ }^{51}$ it found that the lawyers were neither direct violators nor aiders and abettors of their client's violations. ${ }^{52}$ Moreover, the Commission found that the attorneys had not violated standards of professional responsibility because it could not conclude that the attorneys' conduct transgressed standards that were generally accepted at the time. ${ }^{53}$ The Commission did, however, discuss the general standards of professional conduct that should guide lawyers in the future, stating:

[A] lawyer must, in order to discharge his professional responsibilities, make all efforts within reason to persuade his client to avoid or terminate proposed illegal action. Such efforts could include, where appropriate, notification to the board of directors of a corporate client. ${ }^{54}$

The Commission emphasized that the articulation of principles of professional conduct to the special role of the securities lawyer giving disclosure advice to a corporate client was not a simple task. It pointed out that the lawyer is only an adviser and the final judgment and, indeed, responsibility as to what course of conduct is to be taken must lie with the client. The Commission acknowledged that disclosure issues often present difficult choices between multiple shades of gray and that the fact the corporate client is pressing its lawyer hard for the minimum disclosure required by law is, by itself, not an appropriate basis for finding that a 
lawyer must resign or take some extraordinary action. The opinion emphasized that the SEC would not seek to hold lawyers responsible for the good faith exercise of professional judgment even if, in view of hindsight, the advice turned out to be wrong. The Commission was concerned that stiffer requirements might drive a wedge between reporting companies and their outside lawyers and that, under certain circumstances, management would soon realize there was nothing to be gained from consulting such lawyers. ${ }^{55}$ The SEC stated:

The Commission is of the view that the lawyer engages in "unethical or improper professional conduct" under the following circumstances: When a lawyer with significant responsibilities in the effectuation of a company's compliance with the disclosure requirements of the federal securities laws becomes aware that his client is engaged in a substantial and continuing failure to satisfy those disclosure requirements, his continued participation violates professional standards unless he takes prompt steps ["that leads to the conclusion that the lawyer is engaged in efforts to correct the underlying problem, rather than having capitulated to the desires of a strong-willed, but misguided client'] to end the client's non-compliance.

Initially, counseling accurate disclosure is sufficient, even if [the attorney's] advice is not accepted. But there comes a point at which a 
reasonable lawyer must conclude that his advice is not being followed, or even sought in good faith, and that his client is involved in the continuing course of violating the securities laws. At this critical juncture, the lawyer must take further, more affirmative steps in order to avoid the inference that he has been co-opted, willingly or unwillingly, into the scheme of nondisclosure.

So long as a lawyer is acting in good faith in exerting reasonable efforts to prevent violations of the law by his client, his professional obligations have been met. $^{56}$

\section{SEC Standards of Professional Conduct}

Among the many significant provisions of the Sarbanes-Oxley Act, Congress mandated that the SEC promulgate a rule focusing on attorney "up the ladder" reporting with respect to a corporate client when faced with a material violation of fiduciary duty, securities law, or similar violation by a subject corporation or constituent (such as a director, officer or employee). Under Section 307 of SOX, Congress directed the SEC to adopt a rule:

(1) requiring [a subject] attorney to report evidence of a material violation of securities law or breach of fiduciary duty or similar violation by the company or any agent thereof, to the chief legal counsel or the chief executive officer of the company (or the equivalent thereof); and (2) if the counsel or officer does 
not appropriately respond to the evidence (adopting, as necessary, appropriate remedial measures or sanctions with respect to the violation), requiring [such] attorney to report the evidence to the audit committee of the board of directors of the issuer or to another committee of the board of directors comprised solely of directors not employed directly or indirectly by the issuer, or to the board of directors. ${ }^{57}$

Section 307 and a large part of the SEC's response resemble existing ethical standards as set forth by the American Bar Association, the American Law Institute, and the states. ${ }^{58}$ Responding to Congress' directive, the SEC adopted standards implementing "up the ladder" reporting ${ }^{59}$ and recognized the legitimacy of a Qualified Legal Compliance Committee (QLCC) to serve as an alternative. ${ }^{60}$

In its promulgation of its Standards of Professional Conduct for Attorneys, the applicable rules

- require an attorney to report evidence of a material violation, determined according to an objective standard, "up-the-ladder" within the issuer to the chief legal counsel or the chief executive officer of the company or the equivalent;

- require an attorney, if the chief legal counsel or the chief executive officer of the company does not respond appropriately to the evidence, 
to report the evidence to the audit committee, another committee of independent directors, or the full board of directors;

- clarify that the rules cover attorneys providing legal services to an issuer who have an attorney-client relationship with the issuer, and who have notice that documents they are preparing or assisting in preparing will be filed with or submitted to the Commission;

- $\quad$ provide that foreign attorneys who are not admitted in the United States, and who do not advise clients regarding U.S. law, would not be covered by the rule, while foreign attorneys who provide legal advice regarding U.S. law would be covered to the extent they are appearing and practicing before the Commission, unless they provide such advice in consultation with U.S. counsel;

- allow an issuer to establish a "qualified legal compliance committee" (QLCC) as an alternative procedure for reporting evidence of a material violation. Such QLCC would consist of at least one member of the issuer's audit committee, or an equivalent committee of independent directors, and two or more independent board members, and would have the responsibility, among other things, to recommend that an issuer implement an appropriate response to evidence of a material violation. 
One way in which an attorney could satisfy the rule's reporting obligation is by reporting evidence of a material violation to a QLCC;

- allow an attorney, without the consent of an issuer client, to reveal confidential information related to his or her representation to the extent the attorney reasonably believes necessary (1) to prevent the issuer from committing a material violation likely to cause substantial financial injury to the financial interests or property of the issuer or investors; (2) to prevent the issuer from committing an illegal act; or (3) to rectify the consequences of a material violation or illegal act in which the attorney's services have been used;

- $\quad$ state that the rules govern in the event the rules conflict with state law, but will not preempt the ability of a state to impose more rigorous obligations on attorneys that are not inconsistent with the rules; and

- affirmatively state that the rules do not create a private cause of action and that authority to enforce compliance with the rules is vested exclusively with the Commission." ${ }^{61}$

The Commission has taken the position that its Standards of Conduct preempt any conflicting provision of state law, including state ethical standards, that do not meet its minimum requirements. ${ }^{62}$ Not surprisingly, states (such as California), that 
do not permit attorney disclosure of client confidences to prevent financial harm, ${ }^{63}$ disagree with the SEC's position. ${ }^{64}$

\section{Noisy Withdrawal}

In adopting its Standards of Conduct, the Commission declined to adopt the attorney "noisy withdrawal" provisions as proposed by the SEC in an earlier release. ${ }^{65}$ Under this proposal, if the corporate client refused to take appropriate corrective action after counsel dutifully went "up the ladder," counsel was obligated to make a "noisy withdrawal," notifying the SEC that such counsel disaffirmed documents that she had prepared during the course of the representation. ${ }^{66}$ At that time, the Commission said that it was still considering adoption of the noisy withdrawal provision along with certain alternatives. ${ }^{67}$ One of these alternatives would require the affected company (rather than counsel) to notify the Commission of the attorney's withdrawal from representation on the basis that such counsel did not receive a suitable response to a report concerning a material violation. ${ }^{68}$ In view of the time period that has elapsed since these rule proposals, it appears unlikely that the SEC (absent further impetus) will adopt a noisy withdrawal rule.

The making of a noisy withdrawal, of course, sounds a siren that fraud or other grievous misconduct likely is afoot. Corporate fiduciaries and the securities bar (as well as groups such as the American Bar Association) reacted to the SEC's proposal 
with alarm, asserting that such a noisy withdrawal mandate would drive a wedge between attorneys and corporate insiders. ${ }^{69}$ Afraid that counsel would "blow the whistle" (albeit by action rather than words), constituents of the business enterprise would be reluctant to seek legal advice on troubling subjects. ${ }^{70}$ Thus, the proposed provision, according to opponents, would be quite detrimental. ${ }^{71}$ Proponents favoring a noisy withdrawal provision, on the other hand, assert that counsel must have this leverage in order to better ensure that corrective action is taken, thereby protecting the corporate client, its shareholders, and creditors. Hence, faced with the reality that counsel must make a noisy withdrawal if appropriate steps are not undertaken, corporate insiders will be "persuaded" to act in compliance with the law. ${ }^{72}$

Regardless of the SEC's inaction, the noisy withdrawal dilemma continues to impact the corporate/securities practitioner. Depending on the circumstances, an attorney who discovers that a disclosure document that she drafted is materially false and is being relied upon by investors to their financial detriment may not simply withdraw from the representation. That alone may not be sufficient. In such situations, counsel may have to disaffirm her work product, hence making a noisy withdrawal, in order to effectuate the withdrawal. As stated in an ABA Formal Opinion, "where the client avowedly intends to continue to use the lawyer's work product, this amounts to a de facto continuation of representation even if the lawyer 
has ceased to perform any additional work." ${ }^{, 73}$ Hence, "[t]he representation is not completed, any more than the fraud itself is completed." ${ }^{\prime 74}$ Comments to the ABA Model Rules of Professional Conduct provide further support for this position. ${ }^{75}$

Accordingly, counsel who withdraws from representing a client committing fraud or other illegal conduct often would be prudent to do more than "quietly" resign. In such circumstances, it may be appropriate for the attorney to inform the SEC, the applicable state regulator, and/or investors of counsel's withdrawal based on "professional reasons." No client confidence or secret must be revealed. The fact of this communication alone should serve as a "red flag" to government authorities and reasonable investors that illegal or unethical conduct may be present. As importantly, the threat by the attorney to the client that counsel will make this communication if the client fails to take corrective action acts as a powerful measure to induce client compliance. This leverage may well be necessary to avert fraud or illegality, investor financial loss, and the imposition of liability.

Critics of this recommendation perceptively assert that the issues involved in disclosure determinations, such as materiality, ${ }^{76}$ often are problematic. Rather than a clear duty to disclose, variations in the "gray" zone often arise. Without the benefit of hindsight, an attorney's good faith interpretation may prove erroneous. Indeed, public knowledge of an attorney's noisy withdrawal may cause the market price of 
the subject company's stock to plummet. If counsel is mistaken as to the commission of a material violation (when no such violation exists), claims for attorney malpractice, among others, may ensue. Hence, in practical effect, in order to comply with the applicable ethical norms and act in the corporate client's best interests, counsel must be certain that fraud or other major impropriety is afoot before making a noisy withdrawal. Unfortunately, as critics observe, certainty does not frequently prevail in the "real world." 77

The solution to this dilemma is rather straightforward. In situations where an attorney counsels that the corporate client must undertake certain corrective action and that advice is resisted by the independent directors of the board of directors, counsel should insist that the client procure an independent "second opinion" from an unaffiliated lawyer (or law firm).$^{78}$ Although such a second opinion may be costly, may bruise counsel's ego, and may pose a threat that the second opining law firm will "steal" the client, this solution has been recognized for decades and is now firmly entrenched in ethical norms. ${ }^{79}$ Indeed, the SEC Standards of Conduct adopted allow for the procurement of a second opinion to constitute an "appropriate response" under specified circumstances. ${ }^{80}$ The employment of attorney second opinions thus is a sound practice to help persuade corporate insiders that appropriate corrective action is required and serves as a meaningful protective mechanism to minimize attorney 
liability. Hence, use of the "second opinion" in this context normally will enhance the accuracy of the legal advice rendered, thereby serving the best interests of both client and counsel. ${ }^{81}$

\section{Responding to Auditor Requests}

A customary practice of auditors is to transmit audit inquiry letters to client corporations, which thereupon forward such requests to their counsel for assessment and response. Such a letter normally asks counsel to provide the auditor with certain information regarding the client's affairs. The information provided is employed by the auditor in opining on the corporation's annual financial reports. ${ }^{82}$ Among other items, the audit inquiry letter will seek information relating to contingent liabilities. ${ }^{83}$

Such "loss contingency" requests may cause tension. On the one hand, there is counsel's desire to preserve the client's confidences and secrets, as well as the client's desire to avoid disclosure of unfavorable information. For example, disclosure of a contingent unasserted liability may amount to advertising a client's possibly illegal conduct - a particularly undesirable event for the corporation where potential plaintiffs are ignorant of the possible claim. ${ }^{84}$ In addition, disclosure of a client's confidences incurs risk of waiving both the attorney-client and work product privileges. ${ }^{85}$ On the other hand, the auditor has a legitimate need to obtain adequate information in order to fulfill its duties consistent with the policy supporting public 
confidence in published financial statements. ${ }^{86}$

Competing against these considerations is the ever-present threat that an attorney's failure to disclose material facts may subject the attorney and client to liability exposure under the securities laws. ${ }^{87}$ In addition to potential liability for violation of the federal securities acts' antifraud provisions, SEC Rule 13b2-2(b), as amended by the SEC pursuant to the directive set forth in the Sarbanes-Oxley Act, ${ }^{88}$ may raise liability concerns for counsel who allegedly "provide[s] an auditor with an inaccurate or misleading legal analysis." ${ }^{, 9}$

In an effort to resolve these competing interests, the Financial Accounting Standards Board promulgated its Statement of Financial Accounting Standards No. 5 ("SFAS 5") and the ABA adopted its Statement of Policy Regarding Lawyers' Responses To Auditors' Requests for Information. ${ }^{90}$ Pursuant to the truce arrived at through these pronouncements, the following practice has been implemented with respect to "loss contingencies":

When properly requested by the client, it is appropriate for the lawyer to furnish to the auditor information concerning the following matters if the lawyer has been engaged by the client to represent or advise the client professionally with respect thereto and he has devoted substantive attention to them in the form of legal representation or consultation: 
(a) overly threatened or pending litigation, whether or not specified by the client;

(b) a contractually assumed obligation which the client has specifically identified and upon which the client has specifically requested, in the inquiry letter or a supplement thereto, [for] comment to the auditor;

(c) an unasserted possible claim or assessment which the client has specifically identified and upon which the client has specifically requested, in the inquiry letter or a supplement thereto, [for] comment to the auditor. ${ }^{91}$ According to the ABA Policy Statement, counsel normally should not express judgment as to the outcome of claims delineated unless it appears to counsel that an unfavorable outcome is either "probable" or "remote." 92 With respect to unasserted possible claims or assessments, where a potential claimant has not manifested an awareness of the potential claim, disclosure is required only if the client concludes that "(i) it is probable that a claim will be asserted, (ii) there is a reasonable possibility, if the claim is in fact asserted, that the outcome will be unfavorable, and (iii) the liability resulting from such unfavorable outcome would be material to [the company's] financial condition." ${ }^{93}$ Hence, by leaving the decision to reveal contingent liability for unasserted claims to the client, nondisclosure may well be the likely consequence. ${ }^{94}$ 
In the wake of Sarbanes-Oxley, attorneys today face heightened tensions in responding to auditor requests for information. In addition to the long-standing issues addressed above, attorneys must deal with the recent SEC rulemaking concerning improper influence on auditors. ${ }^{95}$ With the SEC's focus on attorneys as gatekeepers, as evidenced by the initiation of dozens of proceedings against legal counsel, ${ }^{96}$ enhanced pressure has been placed upon lawyers in the audit response process. ${ }^{97}$

\section{Predecessor-Successor Counsel Communications}

A significant issue is the extent to which counsel who resigns from a representation due to client fraud can inform prospective successor counsel of the facts and circumstances surrounding the resignation. In In re OPMLeasing Services., Inc., ${ }^{98}$ predecessor counsel maintained a closed-mouth posture, evidently in order to preserve the former client's confidences and secrets. ${ }^{99}$ Such an approach, unfortunately, enables the client to perpetuate its fraudulent conduct, utilizing unwitting successor counsel as a resource to effectuate its objectives.

The justification for predecessor counsel's silence in this situation is unpersuasive. Former counsel should not stand idly by acquiescing in the former client's retention of successor counsel, thereby resulting in further injury to innocent 
victims. In such situations, predecessor counsel should send "red flags" to the inquiring attorney. ${ }^{100}$ For example, predecessor counsel may state: "I'm unable by the ethical rules to explain why I resigned unless the former client gives me permission to tell you." If the prospective client refuses to give such permission, this should signal to the inquiring attorney that the contemplated engagement should be

declined. ${ }^{101}$ In any event, counsel may be prudent to draft a memorandum to the file documenting the contents of the inquiry. ${ }^{102}$

\section{Reality Check - The Role of Circumstantial Evidence}

A lawyer involved in counseling a client involved in fraud or other illegal conduct is, of course, in a difficult position. Counseling appropriate corrective action is essential. If the client declines to adhere to the lawyer's advice, withdrawal from the representation becomes a necessity. ${ }^{103}$ Nevertheless, if the attorney's work product is being used by the client to perpetuate an ongoing fraud, withdrawal alone under certain circumstances may not be sufficient. This is so even if the attorney was unaware of the fraud when rendering advice to the client. ${ }^{104}$

In assessing the practical realities, the role of circumstantial evidence in often key. ${ }^{105}$ Frequently, to avoid liability the attorney must be viewed as credible by the fact-finder. Plaintiffs will allege that, due to the fraud or other misconduct that was 
perpetrated, the attorney "must" have known of the pertinent circumstances during the time of the engagement. In certain situations, other alleged violators will claim that they relied upon the attorney for legal advice and that the attorney was informed of all the material facts. The generous legal fees that lawyers receive may provide the plaintiffs with ammunition for asserting a motive underlying the alleged misconduct. When counsel has an equity stake in the client, this arrangement will be prominently displayed before the jury. ${ }^{106}$ Not surprisingly, if the question of the lawyer's knowledge of the alleged misconduct is one for the jury, the subject attorney should have great concern.

\section{Conclusion}

This Article has addressed a myriad of issues when a corporate/securities attorney's client contemplates or engages in fraudulent conduct. Recent history evidences that counsel has been reluctant to inform the client's independent directors when confronted with senior management transgressions. This disinclination has proven disastrous for the corporate client, its shareholders, employees, and other affected constituencies. Such failure also has saddled subject counsel with enormous monetary liability. A lesson to be learned by counsel from the recent corporate debacles is that use of the "second opinion" mechanism should be resorted to with greater frequency and that the affected client's independent directors, including the 
members of the audit committee, should be better informed of irregularities. If these practices are implemented, instances where counsel must resign or feel obliged to make a "noisy withdrawal" should be rare.

\section{Notes}

* Radford Professor of Law, Southern Methodist University. This Paper was delivered by the author in February 2006 as the Foulston Siefkin Lecturer at the Washburn University School of Law. I thank the law firm of Foulston Siefkin LLP as well as the faculty and students of Washburn Law School for their courtesy and support.

Significant portions of this Article are reprinted with the permission of the publisher and copyright holder from Chapter 3, "Client Fraud," in Attorney Liability After Sarbanes-Oxley by Marc I. Steinberg, published by and copyrighted by ALM Properties, Inc., Law Journal Press, a division of American Lawyer Media, Inc. All rights reserved. Copies of the complete work may be ordered from Law Journal 
Press, Book Fulfillment, 105 Madison Avenue, New York, New York 10016, or on the Web at www.lawcatalog.com.

1. See, e.g., Molecular Technology v. Valentine, 925 F.2d 910 ( $6^{\text {th }}$ Cir. 1991); In re Enron Securities Derivative \& ERISA Litigation, 235 F. Supp. 2 d 549 (S.D. Tex. 2002); Prince v. Brydon, 764 P.2d 1370 (Or. 1988); Thornwood, Inc. v. Jenner \& Block, 799 N.E.2d 756 (Ill. Ct. App. 2003). But see Ziemba v Cascade International, Inc., 256 F.3d $1194\left(11^{\text {th }}\right.$ Cir. 2001). For analysis of case law on this subject, see M. Steinberg, Attorney Liability After Sarbanes-Oxley §§ 2.01-6.06 (2005).

2. See, e.g., Denney v. Jenkens \& Gilchrist, 2005 WL 388562 (S.D.N.Y. 2005) (settlement between law firm and former clients approved for over \$81 million); “KPMG, Sidley reach \$225/M Tax Settlement,” Nat. L.J., Oct. 3, 2005, at p.3; “Arizona Law Firm Pays \$21 Million, Denies Role in Baptist Foundation Collapse,” 34 Sec. Reg. \& L. Rep. (BNA) 602 (2002); Craig and Scannel, “Judges Fraud Ruling Puts Heat on Morgan Stanley, Law Firm,” Wall St. J., March 24, 2005, at p. A1; Davis, “On the Hot Seat," Wall St. J., July 18, 2003, at p. C1; Jones, “Kirkland \& Ellis Gets a Black Eye For Now,” Nat. L.J., April 4, 2005, at p.6; Pollock, “Lawyers for Enron Faulted Its Deals, Didn’t Force Issue,” Wall St. J., May 22, 2002, at p. A1; Schwartz, "Law Firms Hit With More Lawsuits," Nat. 
L.J., May 16, 2005, at p. 11 (stating that "the number of big-ticket suits . . . against [law] firms has risen dramatically since 1996").

3. See Cutler, "The Themes of Sarbanes-Oxley as Reflected in the Commission's Enforcement Program," http://sec.gov/news/speech/spch092004smc.htm at p. 5 (2004) (stating that the SEC has "named lawyers as respondents or defendants in more than 30 of our enforcement actions in the past two years"). For recent SEC enforcement actions against legal counsel, see, e.g., SEC v. Yuen, SEC Litig. Rel. No. 19047 (C.D. Cal. 2005); In re Google, Securities Act Release No. 8523 (SEC 2005); SEC v. Weiss, SEC Litig. Rel. No. 19002 (S.D.N.Y. 2004); proceedings discussed in Steinberg, supra note 1, at $\S \S 4.01-4.03$.

4. See, e.g., United States v. Gordon, 393 F.3d 1044 ( $9^{\text {th }}$ Cir. 2004); NewYork v. Belnick, No. 00145/03 (N.Y. Sup. Ct. 2004) (discussed in "N.Y. Jury Finds ExTyco Counsel Not Guilty on Larceny, Fraud Charges,” 36 Sec. Reg. \& L. Rep. (BNA) 1316 (2004)).

5. See, e.g., Aguirre, "The Enron Decision: Closing the Fraud-Free Zone on Errant Gatekeepers,” 28 Del. J. Corp. L. 447 (2003); Nicholson, “A Hobson’s Choice for Securities Lawyers in the Post-Enron Environment: Striking a Balance Between the Obligations of Client Loyalty and Market Gatekeepers," 16 Geo. J. Leg. Eth. 91 (2002); Oh, “Gatekeeping,” 29 J. Corp. L. 735 (2004); Sommer, “The 
Emerging Responsibilities of the Securities Lawyer," [1973-1974 Transfer Binder]

CCH Fed. Sec. L. Rep. I 79,631 (1974); Steinberg, “Attorney Liability for Client

Fraud," 1991 Colum. Bus. L. Rev. 1 (1991); Zacharias, "Lawyers as Gatekeepers,"

41 San Diego L. Rev. 1387 (2004).

In Lincoln Savings and Loan Association v. Wall, 743 F. Supp. 901 (D.D.C. 1990), Judge Stanley Sporkin inquired:

Where were these professionals, a number of whom are now asserting their rights under the Fifth Amendment, when these clearly improper transactions were being consummated?

Why didn't any of them speak up or disassociate themselves from the transactions?

Where also were the outside accountants and attorneys when these transactions were effectuated?

What is difficult to understand is that with all the professional talent involved (both accounting and legal) why at least one professional would not have blown the whistle to stop the overreaching that took place in this case.

Id. at 920. See Editorial, "Judgment on Lincoln S \& L," Wash. Post, Aug. 8, 1990, at p. A26 (opining that Judge Sporkin's assertion "is a charge to bar 
associations and accounting boards to consider this enormous failure of their professional standards to protect both clients and the public"). Certainly, it may be argued that the recent financial fraud debacles accentuate this point. The revised ABA standards, discussed infra notes 6-14 and accompanying text, and the SEC Standards of Conduct adopted in 2003, discussed infra notes 57-64 and accompanying text, hopefully will ameliorate this problem.

6. See American Bar Association (ABA), Model Rules of Professional Conduct, rule 1.13 (a) (2003); id. rule 1.13 comment 1 (stating that "[a]n organizational client is a legal entity, but it cannot act except through its officers, directors, employees, shareholders and other constituents"). American Law Institute, Restatement of the Law (Third), The Law Governing Lawyers $§ 96$ comment b (2000) (stating that "[a] lawyer who has been employed or retained to represent an organization as a client owes professional duties of loyalty and competence to the organization [and that] [b]y representing the organization, a lawyer does not thereby also form a client-lawyer relationship with all or any individuals employed by it, or who direct its operations or who have an ownership or other beneficial interest in it, such as the shareholders").

7. See Model Rules of Professional Conduct, rule 1.0(e) (defining "knows" to mean "actual knowledge of the fact in question [which] may be inferred from 
circumstances").

8. Id. rule 1.13(b). Comment 3 of Rule 1.13 provides:

When constituents of the organization make decisions for it, the decisions ordinarily must be accepted by the lawyer even if their utility or prudence is doubtful. Decisions concerning policy and operations, including ones entailing serious risk, are not as such in the lawyer's province. Paragraph (b) makes clear, however, that when the lawyer knows that the organization is likely to be substantially injured by action of an officer or other constituent that violates a legal obligation to the organization or is in violation of law that might be imputed to the organization, the lawyer must proceed as is reasonably necessary in the best interest of the organization. As defined in Rule 1.0(f), knowledge can be inferred from circumstances, and a lawyer cannot ignore the obvious.

9. See id. rule 1.16(a) (mandating withdrawal from representation if "the representation will result in violation of the rules of professional conduct or other law"); id. rule 1.16(b) (allowing withdrawal from representation if "the client persists in a course of conduct involving the lawyer's services that the lawyer reasonably believes is criminal or fraudulent [or] the client has used the lawyer's services to perpetuate a crime or fraud"). 
10. See Cal. Bus. And Prof. Code $\S 6068(\mathrm{e})$ (stating that it is an attorney's duty "to maintain inviolate the confidence, and at every peril to himself or herself to preserve the secrets, of his or her client"); California State Bar, Professional Conduct Rules, rule 3-600(c) ("If, despite the member's actions in accordance with paragraph (B), the highest authority that can act on behalf of the organization insists upon action or a refusal to act that is a violation of law and is likely to result in substantial injury to the organization, the member's response is limited to the member's right, and where appropriate, duty to resign in accordance with rule 3-700"); id. rule 3-600 comment 3 (allowing disclosure to nonclients when the lawyer reasonably believes such disclosure "is necessary to prevent a criminal act that the [lawyer] reasonably believes is likely to result in the death of, or substantial bodily harm to an individual").

11. Today, over forty states permit or require an attorney to reveal a client's crime or fraud that threatens substantial financial loss. See American Law Institute, Restatement (Third) of the Law Governing Lawyers $\S 67$ comment b (2000). Accord, ABA Model Rules of Professional Conduct, rules 1.6(b)(2), 1.13(e). See Kansas Rules of Professional Conduct, rule 1.6(b)(1) (allowing a lawyer to "reveal such information to the extent the lawyer reasonably believes necessary ... [t]o prevent the client from committing a crime"); N.Y. Code of Professional 
Responsibility DR 4-101(c)(3) (allowing the attorney to reveal information concerning " $[\mathrm{t}]$ he intention of a client to commit a crime and the information necessary to prevent the crime"). In addition, several states allow counsel to reveal confidential information to nonclients "to the extent revelation reasonably appears necessary to rectify the consequences of a client's criminal or fraudulent act in the commission of which the lawyer's services had been used." Texas Disciplinary Rules of Professional Conduct, rule 1.05(c)(8). Accord, ABA Model Rules of Professional Conduct, rule 1.6(b)(3); ALI, Restatement (Third) of the Law Governing Lawyers $\S 67(2)$. A few states require disclosure of client fraud in this context. See, e.g., New Jersey Rules of Professional Conduct, rule 1.6(b). Also, a number of states mandate that counsel make a "noisy" withdrawal. See, e.g., Tennessee Rules of Professional Conduct, rule 4.1(b), (c). See generally M. Steinberg, Lawyering and Ethics for the Business Attorney 15-28 (2002); Cramton, "Enron and the Corporate Lawyer: A Primer on Legal and Ethical Issues," 58 Bus. Law. 143 (2002); Simon, "Whom (or What) Does the Organization's Lawyer Represent? An Anatomy of Intraclient Conflict," 91 Calif. L. Rev. 57 (2003).

12. ABA, Model Rules of Professional Conduct, rule 1.2(d). See id. rule 1.2 comment 10: 
When the client's course of action has already begun and is continuing, the lawyer's responsibility is especially delicate. The lawyer is required to avoid assisting the client, for example, by drafting or delivering documents that the lawyer knows are fraudulent or by suggesting how the wrongdoing might be concealed. A lawyer may not continue assisting a client in conduct that the lawyer originally supposed was legally proper but then discovers is criminal or fraudulent. The lawyer must, therefore, withdraw from the representation of the client in the matter. See Rule 1.16(a). In some cases, withdrawal alone might be insufficient. It may be necessary for the lawyer to give notice of the fact of withdrawal and to disaffirm any opinion, document, affirmation or the like. See Rule 4.1. 13. For further discussion, see Glazer, Fitzgibbon and Weise, Legal Opinions (2d ed. 2004); Steinberg, supra note 1 , at $\S \S 2.05,11.03$.

14. See ABA, Model Rules of Professional Conduct, rule 4.1. 15. See, e.g., Illinois Rules of Professional Conduct, rule 4.1 (setting forth reasonably should have known standard).

16. Section 10(b) of the Securities Exchange Act of 1934, 15 U.S.C. $\S 77 j$ (b). 17. See, e.g., Fortson v. Winstead, McGuire, Sechrest \& Minick, 961 F.2d 469, 472 ( $4^{\text {th }}$ Cir. 1992), citing, Chiarella v. United States, 445 U.S. 222, 228 (1980) (quoting Restatement (Second) of Torts § 551(2)(a) (1976)). See also, Schatz v. 
Rosenberg, 943 F.2d 485, 490 ( $4^{\text {th }}$ Cir. 1991) (holding that a lawyer or law firm cannot be held liable for misrepresentation under $\S 10(\mathrm{~b})$ for failing to disclose information about a client to a third party absent some fiduciary or other confidential relationship with the third party); Abell v. Potomac Insurance Co., 858 F.2d $1104,1124-1126\left(5^{\text {th }}\right.$ Cir. 1988), judgment vacated on other grounds, 492 U.S. 914 (1989) (holding legal counsel had no affirmative duty to disclose under $§ 10(b))$; Barker v. Henderson, Franklin, Starnes \& Holt, 797 F.2d 490, 496 ( $7^{\text {th }}$ Cir. 1986) ("Neither lawyers nor accountants are required to tattle on their clients in the absence of some duty to disclose.”); Lycan v. Walters, 904 F. Supp. 884, 901 (S.D. Ind. 1995) (stating that no evidence was offered to suggest that the attorney owed the nonclients "any duty to disclose [and that] [w]ithout such a duty, any omission by [counsel] would not support a claim under $10 \mathrm{~b}-5$ or $10(\mathrm{~b})$ "). 18. See, e.g., Fortson v. Winstead, McGuire, Sechrest \& Minick, 961 F.2d at 472; Schatz v. Rosenberg, 943 F.2d at 490-492; Barker v. Henderson, Franklin, Starnes \& Holt, 797 F.2d at 496.

19. See 37 C.J.S. Fraud $\S 61(b)(3)$ (1943) ("Mere silence in the face of a third person's fraud will not render defendant liable unless there is a duty to speak."). 20. Fortson, 961 F.2d at 272 (citing Windon Third Oil \& Gas Drilling Partnership v. FDIC, 805 F.2d 342, $347\left(10^{\text {th }}\right.$ Cir. 1986)). See Chiarella v. United States, 445 
U.S. 222, 228 (1980) (holding in $\S 10(b)$ insider trading context duty to disclose arises from a fiduciary or similar relationship of trust and confidence); Barker, 797 F.2d at 496 (finding that because neither $\S 10(b)$ nor Rule 10b-5 imposes such a duty to disclose, any such duty "must come from a fiduciary relation outside the securities law"). See generally W. Wang and M. Steinberg, Insider Trading (2d ed. 2005).

Note that a relatively small number of state ethical codes mandate attorney disclosure of client fraud. See, e.g., N.J. Rules of Professional Conduct, rule 1.6(b)(1) (requiring a lawyer to reveal client confidences when the client's actions are "likely to result in ... substantial injury to the financial interest or property of another"). Also, a number of states require counsel when faced with client fraud or illegality to make a noisy withdrawal under specified conditions. See, e.g, Tennessee Rules of Professional Conduct, rule 4.1(b), (c).

21. See sources cited supra notes 2-5. See also, Meyerhofer v. Empire Fire \& Marine Insurance Co., 497 F.2d 1190, 1192-1193 (2d Cir. 1974).

22. Barker v. Henderson, Franklin, Starnes \& Holt, 797 F.2d 490, 496 ( $7^{\text {th }}$ Cir. 1986).

23. Id. at 497. See cases cited supra note 2. Note, however, language contained in a few decisions suggest that counsel may have an independent disclosure 
obligation. See, e.g., Felts v. National Accounting System Associations, Inc., [1979 Transfer Binder] CCH Fed. Sec. L. Rep. ๆ 96,890, at p. 95,520 (N.D. Miss. 1978). See also, SEC v. National Student Marketing Corp., [1971-1972 Transfer Binder] CCH Fed. Sec. L. Rep. ๆ 93,360, at pp. 91,913-91,917 (D.D.C. 1972) (SEC complaint alleging subject company's lawyers had duty to disclose client's illegality to the SEC).

24. See, e.g., Bernstein v. Portland Savings and Loan Association, 850 S.W. 2d 694 (Tex. App. 1993):

The ... cases that outline fraud through silence do not create in lawyers a duty to disclose confidential information about their client to third parties; this absence of duty is emphasized when the lawyer has no fiduciary or confidential relationship with that third party. The state bar rules indicate that the duty runs to the client and to remain silent. We look to these rules as guides, not as binding law. Attorneys are barred from knowingly revealing confidential information about their clients by the Supreme Court of Texas, Rules Governing the State Bar of Texas (SBR)... . This rule is tempered by Rule 1.05(c)(7), which states that attorneys may reveal confidential information in order to prevent the client from committing a fraudulent act.... Even if the attorneys have 
confidential information "clearly establishing that a client is likely to commit a ... fraudulent act," they are only required to reveal confidential information if that act is likely to result in death or substantial bodily harm to a person.... Because the Texas Supreme Court has chosen not to force attorneys to disclose client confidences to avert non-violent fraud by clients, we decline to do so as well.

Id. at 701 (emphasis in original). See generally, Symposium, "The Role of a Corporate Lawyer," 33 Capital U.L. Rev. No. 1 (2004); Symposium, "Ethics in Corporate Representation,” 74 Fordham L. Rev. No. 3 (2005); Symposium, "Enron: Lessons and Implications," 8 Stan. J. Law Bus. \& Fin. No. 1 (2002); Symposium, "Lessons from Enron, How Did Corporate and Securities Law Fail?," 48 Vill. L. Rev. No. 4 (2003); Langevoort, “'Where Were the Lawyers? A Behavioral Inquiry Into Lawyers' Responsibility for Clients' Fraud," 46 Vand. L. Rev. 75 (1993); Painter and Duggan, "Lawyer Disclosure of Corporate Fraud:

Establishing a Firm Foundation," 50 SMU L. Rev. 225 (1996); Phillips, "Client Fraud and the Securities Lawyer's Duty of Confidentiality," 49 Wash. \& Lee L. Rev. 923 (1992); Steckman, “Attorney Liability for Client Fraud,” 28 Sec. Reg. L.J. 207 (2000); Veasey, “Counseling Directors in the New Corporate Culture, 59 Bus. Law. 1447 (2004). 
25. See, e.g., “Attorney's Conduct in Issuing an Opinion Letter Without

Conducting an Inquiry of Underlying Facts Failed to Comport with Applicable Standards of Conduct," Securities Exchange Act Release No. 17831, 22 SEC

Docket 1200 (1981) (Section 21(a) Report) (asserting that counsel's inquiry was "totally inadequate and facilitated the bond closing and bond sales to the public," the Commission, drawing on ABA Formal Opinion 335, stated: "Unless lawyers, carefully and competently ascertain the relevant facts and make a reasonable inquiry of their clients to obtain facts not within their personal knowledge, their opinions may facilitate fraudulent transactions in securities. This is so particularly as the investing public looks to the lawyer's opinion as a safeguard against violations of the federal securities laws." 22 SEC Docket at 1202).

Another example is the SEC's response to the "Georgetown Petition" where the Commission was requested to adopt three proposed rules, which would have had the effect of amending the Commission's disclosure forms to require disclosure by corporations of: (1) certification by the board of directors that it has instructed all attorneys employed or retained by the corporation to report to the board certain corporate activities discovered by the attorney which, in the attorney's opinion, violate or probably violate the law; (2) written agreements between the corporation and outside counsel which specify, among other things, 
the frequency and nature of counsel's contacts with the board of directors; and (3) the circumstances of resignations or dismissals of general counsel or securities attorneys of the corporation. Securities Exchange Act Release No. 16045, 17 SEC Docket 1376 (1979). The Commission put out the request for public comment, without taking a position on the merits of the proposal. The Commission received over 300 public comments regarding this proposal. Subsequently, the Commission determined to deny the petition. Securities Exchange Act Release No. 16769, 19 SEC Docket 1300 (1980).

In its release denying the petition, the Commission noted that one of the several reasons for denial urged by commentators was that many of the questions concerning "the nature of the obligations of attorneys to make appropriate disclosure of corporate illegalities they discover" were being addressed in the private sector. 19 SEC Docket at 1301. Thus, the Commission expressed the view that "it would be inappropriate, at this time, to consider further the rules proposed by the Institute" in light of the concerns expressed by the commentators, "particularly with respect to ... the initiative in this area being taken by the legal profession. ..." Id. at 1302 .

26. See, e.g., In re Google, Securities Act Release No. 8523 (SEC 2004); In re Isselmann, Securities Exchange Act Release No. 50428 (SEC 2004); In re Watt, 
Securities Exchange Act Release No. 46899 (SEC 2002).

27. See, e.g., SEC v. Cavanagh, 155 F.3d 129 (2d Cir. 1998); SEC v. Haswell, 654 F.2d 698 (10 ${ }^{\text {th }}$ Cir. 1981); SEC v. National Student Marketing Corp., 457 F.

Supp. 682 (D.D.C. 1978).

28. See, e.g., proceedings cited infra notes 32-33.

29. See proceedings cited infra notes 32-56.

30. In re Fields, [1972-1973 Transfer Binder] CCH Fed. Sec. L. Rep. ๆ 79,407

(SEC 1973), aff'd without opinion, 495 F.2d 1075 (D.C. Cir. 1974).

31. Id. at pp. $83,174-83,175$ n.20. The Commission also stated that the securities lawyer "works in his office where he prepares prospectuses, proxy statements, opinions of counsel, and other documents that we, our staff, the financial community, and the investing public must take on faith."

32. In re Keating, Muething \& Klekamp, Securities Exchange Act Release No. 15982, [1979 Transfer Binder] CCH Fed Sec. L. Rep. ๆ 82,124 (SEC 1979). See In re Plotkin, Yolles, Siegel and Turner, Securities Act Release No. 5841, 12 SEC Docket 263 (SEC 1977); In re Ferguson, Securities Act Release No. 5523, 5 SEC Docket 37 (SEC 1974). See Steinberg, "Attorney Liability for Client Fraud," 1991 Colum. Bus. L. Rev. 1, 20-21 (1991):

With respect to the adequacy of law firm internal procedures, In re Keating stands for the proposition that lawyers in a firm should 
communicate with one another when preparing disclosure documents, such as SEC filings. In the context of federal securities law practice, an adequate system helps to ensure that the material facts concerning a client that are known to individual lawyers of the firm are communicated to those attorneys in the firm who draft the disclosure documents. By implementing sufficient procedures, a law firm adequately discloses material facts relating to a client that are within the firm's possession.

Id. Significantly, the SEC pointed out in In re Keating that "[t]his case generally does not involve the extent to which law firms have a duty to inquire of a client for information. We are here speaking only about that information already possessed by the firm.” [1979 Transfer Binder] CCH Fed. Sec. L. Rep. ๆ 82,124, at p. 81,989 n.13. With respect to the SEC Standards of Conduct, discussed infra notes 57-64 and accompanying text, one source has asserted:

[T] he existence of [the SEC Standards of Conduct] obligation may spur the creation of internal systems within law firms for identifying potential client wrongdoing and responding more self-consciously and with more levels of review. Systems of that type may reduce the vulnerability of law firms to the poor decisions of partners whose individual stakes in a client have compromised their objectivity. In other words, the rules may lead to the 
establishment of institutional bulwarks against avoidance and rationalization.

Sargent, "Lawyers in the Perfect Storm, 43 Washburn L.J. 1, 38 (2003).

33. For recent proceedings against attorneys, see, e.g., In the Matter of Campbell, Securities Exchange Act Release No. 50906 (2004); In the Matter of Smith, Securities Exchange Act Release No. 50566 (2004); In the Matter of Oliver, Securities Exchange Act Release No. 50565 (2004); In the Matter of Labertew, Securities Exchange Act Release No. 49039 (2004); proceedings cited infra notes 36-56. Rule 102(e) proceedings normally are public unless the Commission, at a party's request or on its own motion, orders that a particular Rule 102(e) proceeding be private. See Securities Exchange Act Release No. 25893, [19871988 Transfer Binder] CCH Fed. Sec. L. Rep. ๆ 84,248 (1988).

34. An original proceeding pursuant to Rule 102(e) is conducted as an administrative proceeding before a federal administrative law judge with a right to review by the Commission and judicial review by a United States Court of Appeals. Some orders imposing restrictions on practice, however, are entered as a result of an SEC enforcement action, such as an injunction, or a felony conviction, or by consent in settlement of outstanding charges. "Practicing" before the Commission, as defined in Rule 102(g), "shall include, but shall not be limited to 
(1) transacting any business with the Commission; and (2) the preparation of any statement, opinion or other paper by any attorney, accountant, engineer or other expert, filed with the Commission in any registration statement, notification, application, report or other document with the consent of such attorney, accountant, engineer or other expert." See also, SEC v. Ezrine, Civil Action No. 73-3121 (S.D.N.Y. 1972), where the district court defined "practicing" as: ... participating, in a representative capacity, in any administrative proceeding, investigation, or conference concerning matters within the Commission's jurisdiction, (b) participating, in a representative capacity, in connection with matters within the Commission's jurisdiction when it appears or reasonably should appear that a Commission proceeding or investigation will be instituted therewith, (c) representing any broker or dealer, investment company or investment advisor registered with the Commission in connection with any matter arising under or relating to the federal securities laws and (d) representing or advising any entity or person in connection with the preparation or filing of documents as may be required to be filed with the Commission under the federal securities laws.

See SEC Litigation Release No. 5495 at n.26 (1972).

35. See SOX $\S 602$, adding, $\S 4 \mathrm{C}$ (a) to the Securities Exchange Act. 
36. See, e.g., In re Keating, Muething \& Klekamp, [1979 Transfer Binder] CCH Fed. Sec. L. Rep. ๆ 82,124, at p. 81,981 (SEC 1979) (dissenting opinion). See also, Downing and Miller, "The Distortion and Misuse of Rule 2(e)," 54 Notre Dame Law. 784 (1979); Fiflis, “Current Problems of Accountant's Responsibilities to Third Parties," 28 Vand. L. Rev. 31, 63-64 (1975); Kelleher, "Scourging the Moneylenders from the Temple: The SEC, Rule 2(e), and the Lawyers," 17 San Diego L. Rev. 501 (1980); Krane, “The Attorney Unshackled: SEC Rule 2(e) Violates the Client's Sixth Amendment Right to Counsel," 57 Notre Dame Law. 50 (1981); Seamons, "Inside the Labyrinth of the Elusive Standard Under the SEC's Rule 2(e)," 23 Sec. Reg. L.J. 57 (1977); Note, “SEC Disciplinary Proceedings Against Attorneys Under Rule 2(e)," 79 Mich. L. Rev. $1270(1981)$.

In 1998, the SEC amended Rule 102(e). Securities Act Release No. 7593, [1998 Transfer Binder] CCH Fed. Sec. L. Rep. ๆ 86,052 (1998). As amended, Rule 102(e)(1)(ii) defines "improper professional conduct" for accountants to mean:

(A) Intentional or knowing conduct, including reckless conduct, that results in a violation of applicable professional standards; or

(B) Either of the following two types of negligent conduct: 
(1) A single instance of highly unreasonable conduct that results in a violation of applicable professional standards in circumstances in which an accountant knows, or should know, that heightened scrutiny is warranted.

(2) Repeated instances of unreasonable conduct, each resulting in a violation of applicable professional standards, that indicate a lack of competence to practice before the Commission.

In the enactment of the Sarbanes-Oxley Act, Congress codified this interpretation. SOX $\S 602$, adding, $\S 4 \mathrm{C}(\mathrm{b})$ to the Securities Exchange Act. 37. See, e.g., Answering Brief of the SEC at p. 15 in Touche Ross \& Co. v. SEC, 609 F.2d 570 (2d Cir. 1979).

38. SOX $\S 602$, adding, $\S 4 \mathrm{C}$ to the Securities Exchange Act. 39. See, e.g., Marrie v. SEC, 374 F.3d 1196 (D.C. Cir. 2004) (reversing SEC order against subject accountants on basis that applicable standard was not clear at the time of the alleged misconduct); Checkowsky v. SEC, 139 F.3d 221 (D.C. Cir. 1998) (dismissing Rule 102(e) proceeding against two auditors because of Commission's failure to define applicable legal standard). 40. See, e.g., Checkowsky v. SEC, 23 F.3d 452 (D.C. Cir. 1994); Touche Ross \& Co. v. SEC, 609 F.2d 570 (2d Cir. 1979); Koden v. U.S. Department of Justice, 
564 F.2d 228, 234 ( $7^{\text {th }}$ Cir. 1977); SEC v. Csapo, 533 F.2d 7, 12 (D.C. Cir. 1976);

Fields v. SEC, 495 F.2d 1075 (D.C. Cir. 1974); Kivitz v. SEC, 475 F.2d 956 (D.C.

Cir. 1973); Schwebel v. Orrick, 153 F. Supp. 701, 704 (D.D.C. 1957), aff'd on

other grounds, 251 F.2d 919 (D.C. Cir.), cert. denied, 356 U.S. 927 (1958).

See generally, Callcott, "D.C. Circuit Casts Doubt on The Breadth of SEC Rule 2(e)," 8 Insights No. 10, at p. 10 (Oct. 1994); Dolin, "SEC Rule 2(e) After Carter-Johnson and Toward a Reconciliation of Purpose and Scope," 9 Sec. Reg. L.J. 331 (1982); Goelzer and Wyderko, "Rule 2(e): Securities and Exchange Commission Discipline of Professionals," 85 Nw. U.L. Rev. 652 (1991); Gruenbaum, "The SEC's Use of Rule 2(e) to Discipline Accountants and Other Professionals," 56 Notre Dame Law. 820 (1981); Lorne and Callcott, "Administrative Actions Against Lawyers Before the SEC," 50 Bus. Law. 1293 (1995); Marsh, "Rule 2(e) Proceedings," 35 Bus. Law. 987 (1980); "Report of the Task Force on Rule 102(e) Proceedings: Rule 102(e) Sanctions Against Accountants," 52 Bus. Law. 965 (1997); Maxey, "SEC Enforcement Actions Against Securities Lawyers: New Remedies vs. Old Policies,” 22 Del. J. Corp. 537 (1997); Russell, "Cries and Whispers: Environmental Hazards, Model Rule 1.6, and the Attorney's Conflicting Duties to Clients and Others," 72 Wash. L. Rev. 409 (1997). 
41. 609 F.2d 570 (2d Cir. 1979).

42. Id. at 581, quoting, United States v. Benjamin, 328 F.2d 854, 863 (2d Cir. 1964).

43. 609 F.2d at 582. Accord, Davy v. SEC, 792 F.2d 1418 ( $9^{\text {th }}$ Cir. 1986). See also, KPMG LLP v. SEC, 289 F.3d 109 (D.C. Cir. 2002) (rejecting argument that Rule 102(e) is the exclusive means for the SEC to address alleged accountant misconduct).

44. See 609 F.2d at 582 n.21.

45. In re Keating, Muething Klekamp, [1979 Transfer Binder] CCH Fed. Sec. L.

Rep. ๆ 82,124, at pp. 81,988-81,989 (SEC 1979).

46. Id. at p. 81,988 .

47. In re Carter and Johnson, [1981 Transfer Binder] CCH Fed. Sec. L. Rep. ๆ 82,847 (SEC 1981).

48. Answering Brief of the Office of the General Counsel at 99-106, In re Carter and Johnson, File No. 3-5464 (1979).

49. In re Carter and Johnson, [1981 Transfer Binder] CCH Fed. Sec. L. Rep. ๆ 82,847 (SEC 1981).

50. In re Carter and Johnson, [1979 Transfer Binder] CCH Fed. L. Rep. ๆ 82,175 (1979).

51. In re Carter and Johnson, [1981 Transfer Binder] CCH Fed. L. Rep. 
I 82,847, at pp. 84,146-84,150 (SEC 1981).

52. Id. at pp. $84,167-84,169$.

53. Id. at pp. $84,169-84,170$.

54. Id. at pp. 84,170 .

55. Id. at pp. $84,169-84,172$.

56. Id. at pp. $84,172-84,173$. There was no issue in the case as to whether the lawyer had a duty to make public disclosure of the confidences and secrets of the corporate client.

57. SOX $\S 307,15$ U.S.C. $\S 7245$. Note that the statute encompasses not only a material violation of securities law but also a "breach of fiduciary duty or similar violation by the company or any agent thereof ...." With respect to up-theladder reporting, one source has opined:

The nature of the legal market gives lawyers - both in-house and outside counsel - strong incentives to overlook management wrongdoing. As to the former, even if the in-house general counsel is formally appointed by the board of directors, his tenure normally depends mainly on his relationship with the CEO. As for outside legal counsel, they also must please management in order to retain the firm's business and to attract the business of future clients. This pressure is especially true given the large number of capable firms and attorneys available for hire; law firms are 
something akin to a fungible good. ... Hence, outside counsel likely will be reluctant to pursue management conduct aggressively by reporting it to the board of directors.

Bainbridge and Johnson, "Managerialism, Legal Ethics, and Sarbanes-Oxley Section 307,” 2004 Mich. St. L. Rev. 299, 306-307 (2004).

58. See supra notes 6-14 and accompanying text. Note, however, that the SEC Standards do not have a knowledge requirement to trigger application. See infra notes 59,61 .

59. Implementing Standards of Professional Conduct for Attorneys, Securities Exchange Act Release No. 47276, [2002-2003 Transfer Binder] CCH Fed. Sec. L. Rep. - 86,823 (2003) (codified at 17 C.F.R. pt. 205). The SEC Standards define evidence of a material violation as meaning "credible evidence, based upon which it would be unreasonable, under the circumstances, for a prudent and competent attorney not to conclude that it is reasonably likely that a material violation has occurred, is ongoing, or about to occur.” 17 C.F.R. § 205.2(e). Under the SEC Standards, subordinate lawyers generally may satisfy this obligation by informing their supervisory attorney of evidence of material violation(s). See id. $\S 205.5$ (c). For all of its emphasis on "plain English" (see, e.g., Plain English Disclosure, Securities Act Release No. 7497 (1998) (codified at 17 C.F.R. pt. 228, 229), the 
SEC should do better when adopting standards that regulated persons must follow. See Norris, "No Positives in This Legal Double Negative," N.Y. Times, Jan. 24, 2003, at C1 (criticizing language and context of definition of "evidence of a material violation").

The SEC Standards define the term "appropriate response" as follows: Appropriate response means a response to an attorney regarding reported evidence of a material violation as a result of which the attorney reasonably believes:

(1) That no material violation, as defined in paragraph (i) of this rule, has occurred, is ongoing, or is about to occur;

(2) That the issuer has, as necessary, adopted appropriate remedial measures, including appropriate steps or sanctions to stop any material violations that are ongoing, to prevent any material violation that has yet to occur, and to remedy or otherwise appropriately address any material violation that has already occurred and to minimize the likelihood of its recurrence; or

(3) That the issuer, with the consent of the issuer's board of directors, a committee thereof to whom a report could be made pursuant to Rule 3(b)(3), or a qualified legal compliance committee, has retained or directed 
an attorney to review the reported evidence of a material violation and either:

(i) Has substantially implemented any remedial recommendations made by such attorney after a reasonable investigation and evaluation of the reported evidence; or

(ii) Has been advised that such attorney may, consistent with his or her professional obligations, assert a colorable defense of behalf of the issuer (or the issuer's officer, director, employee, or agent, as the case may be) in any investigation or judicial or administrative proceeding relating to the reported evidence of a material violation.

17 C.F.R. $\S 205.2(b)$.

60. As defined in Section 205.2(k) of the SEC Standards, a Qualified Legal Compliance Committee (QLCC) is a committee of a publicly-held issuer (which committee may also be the audit or other committee of the issuer) that:

(1) Consists of at least one member of the issuer's audit committee (or, if the issuer has no audit committee, one member from an equivalent committee of independent directors) and two or more members of the issuer's board of directors who are not employed, directly or indirectly, by 
the issuer and who are not, in the case of a registered investment company, "interested persons" as defined in section 2(a)(19) of the Investment Company Act of 1940 (15 U.S.C. 80a-2(a)(19));

(2) Has adopted written procedures for the confidential receipt, retention, and consideration of any report of evidence of a material violation under $\S 205.3$;

(3) Has been duly established by the issuer's board of directors, with the authority and responsibility:

(i) To inform the issuer's chief legal officer and chief executive officer (or the equivalents thereof) of any report of evidence of a material violation (except in the circumstances described in $\S$ 205.3(b)(4));

(ii) To determine whether an investigation is necessary regarding any report of evidence of a material violation by the issuer, its officers, directors, employees or agents and, if it determines an investigation is necessary or appropriate, to:

(A) Notify the audit committee or the full board of trustees;

(B) Initiate an investigation, which may be conducted either by the chief legal officer (or the equivalents thereof) or by outside 
attorneys; and

(C) Retain such additional expert personnel as the committee deems necessary; and

(iii) At the conclusion of any such investigation, to:

(A) Recommend, by majority vote, that the issuer implement an appropriate response to evidence of a material violation; and (B) Inform the chief legal officer and the chief executive officer (or the equivalents thereof) and the board of directors of the results of any such investigation under this section and the appropriate remedial measures to be adopted; and

(4) Has the authority and responsibility, acting by majority vote, to take all other appropriate action, including the authority to notify the Commission in the event that the issuer fails in any material respect to implement an appropriate response that the qualified legal compliance committee has recommended the issuer to take.

17 C.F.R. $\S 205.2(\mathrm{k})$. At this time, it appears that the QLCC option may not be widely adopted. See McTague and Brady, "QLCC Option in New Conduct Rule Could Be Disadvantage to Corporate G.C.," 35 Sec. Reg. \& L. Rep. (BNA) 354 (2003). Indeed, as of September 30, 2005, only 456 registrants had established a 
QLCC, amounting to less than four percent of all publicly-held entities. See Rosen, "Resistances to Reforming Corporate Governance: The Diffusion of QLCCS,” 74 Fordham L. Rev. 1251, 1252 (2005).

61. SEC Press Release No. 2003-13 (Jan. 23, 2003). Note that the up-the-ladder provision "is triggered even if the attorney learns of violations that have nothing to do with what the attorney is working on and even if they are unrelated to the attorney’s services." "DC Bar Panelists Discuss Attorney Liability Under Sarbanes-Oxley Act," SEC Today, Vol. 2005-82 (April 29, 2005). For a critical article analyzing the SEC Standards in depth, see Cramton, Cohen and Koniak, "Legal and Ethical Duties of Lawyers After Sarbanes-Oxley," 49 Vill. L. Rev. 725 (2004). Note that unlike Rule 1.13(b) of the ABA's Model Rules of Professional Conduct, which requires knowledge on the attorney's part, the SEC sets forth a murky objective standard. See 17 C.F.R. § 205.2(e); supra note 59. 62. 17 C.F.R. $\S 205.1$ (stating that "[w] here the standards of a state or other United States jurisdiction where an attorney is admitted or practices conflict with this part, this part shall govern").

63. See Cal. Bus. and Prof. Code $§ 6068(\mathrm{e})$; California State Bar, Professional Conduct Rules, rule 3-600(c). 64. See Reisinger, "Two State Bars [California and Washington] Protest SEC 
Rule,” Nat. L.J., Sept. 15, 2003, at p. 1; “Washington Ethics Opinion Portends

Clash Between SEC, State Rules on Revealing Fraud," 35 Sec. Reg. \& L. Rep. (BNA) 1334 (2003); Speech by SEC General Counsel Giovanni P. Prezioso Before the American Bar Association, Section of Business Law (Seattle Wash. April 3, 2004), http://www.sec.gov/news/speech/spch040304gpp.htm. See generally Symposium, "The Evolving Legal and Ethical Role of the Corporate Attorney After the Sarbanes-Oxley Act of 2002," 52 Am. U. L. Rev. No. 3 (2003); Symposium, "The Ethics 2000 Commission: The Adversary System and the Lawyer-Client Relationship," 70 Tenn. L. Rev. No. 1 (2002); Symposium, "Ethics in Corporate Governance," 3 Wyo. L. Rev. No. 2 (2003); Cramton, Cohen, and Koniak, supra note 61; Groskaufmanis, “Climbing 'Up-the-Ladder':

Corporate Counsel and the SEC's Reporting Requirement for Lawyers," 89

Cornell L. Rev. 511 (2004); Hazen, “Administrative Law Controls on Attorney Practice - A Look at the Securities and Exchange Commission's Lawyer Conduct Rules," 55 Admin. L. Rev. 323 (2003); Karmel, "The Securities and Exchange Commission Goes Abroad to Regulate Corporate Governance," 33 Stetson L. Rev. 849 (2004); Winer and Bruch, "The SEC Standards of Professional Conduct: Practicing Law Under the New Regime,” 35 Sec. Reg. \& L. Rep. (BNA) 391 (2003). 
65. See Securities Exchange Act Release No. 47276, [2002-2003 Transfer Binder]

CCH Fed. Sec. L. Rep. ๆ 86,823 (2003).

66. See Securities Exchange Act Release No. 46868, [2002-2003 Transfer Binder]

CCH Fed. Sec. L. Rep. ๆ 86,802 (2002) (setting forth proposed $§ 205.3(d)$ ). As used in the proposed rule, "disaffirm" means:

Disaffirm to the Commission, in writing, any opinion, document, affirmation, representation, characterization, or the like in a document filed with or submitted to the Commission, or incorporated into such a document, that the attorney has prepared or assisted in preparing and that the attorney reasonably believes is or may be materially false or misleading.

Id. at p. 86,541. Interestingly, as set forth in Section 11(b)(1) and (b)(2) of the Securities Act, a subject defendant (including a lawyer who expertises the registration statement or who serves as a director of the issuer) may avoid liability by making a noisy withdrawal:

Before the effective date of the registration statement or part thereof in question, he/she (1) resigns from or takes such steps as are permitted by law to resign from, or ceases or refuses to act in, every office, capacity or relationship ascribed to him/her in the registration statement, and (2) advises the SEC and the issuer in writing of the action taken and disavowing 
responsibility for such part of the registration statement.

After such part of the registration statement has become effective, (1) if he/she was unaware that it had become effective, and, (2) upon becoming aware of such fact, acts forthwith, (3) advises the SEC in writing as set forth above, and (4) gives reasonable public notice that such part of the registration statement had become effective without her/his knowledge.

M. Steinberg, Securities Regulation 414 ( $4^{\text {th }}$ ed. 2004), interpreting, 15 U.S.C. $\S 77 \mathrm{k}(\mathrm{b})(1),(\mathrm{b})(2)$.

67. See Securities Exchange Act Release No. 47282, [2002-2003 Transfer Binder] CCH Fed. Sec. L. Rep. ๆ 86,824 (2003).

68. Id. at p. 87,117. See SEC Press Release No. 2003-13 (Jan. 23, 2003):

The Commission voted to extend for 60 days the comment period on the "noisy withdrawal" and related provisions originally included in [the] proposed [standard]. Given the significance and complexity of the issues involved, including the implications of a reporting out requirement on the relationship between issuers and their counsel, the Commission decided to continue to seek comment and give thoughtful consideration to these issues.

The Commission also voted to propose an alternative to "noisy withdrawal" that would require attorney withdrawal, but would require an 
issuer, rather than an attorney, to publicly disclose the attorney's withdrawal or written notice that the attorney did not receive an appropriate response to a report of a material violation. Specifically, an issuer that has received notice of an attorney's withdrawal would be required to report the notice and the circumstances related thereto on form $8-\mathrm{K}, 20-\mathrm{F}$, or $40-\mathrm{F}$, as applicable, within two days of receiving the attorney's notice. Accordingly, the proposal includes proposed amendments to forms $8-\mathrm{K}, 20-\mathrm{F}$, and $40-\mathrm{F}$ to require issuers to report an attorney's written notice under the proposed rule. The proposing release also will seek comment on whether there are circumstances in which an issuer should be permitted not to disclose an attorney's written notice.

The proposed rules also would permit an attorney, if an issuer has not complied with the disclosure requirement, to inform the Commission that the attorney has withdrawn from representing the issuer or provided the issuer with notice that the attorney has not received an appropriate response to a report of a material violation.

Id.

69. See Atkins, “Attorneys Call for Delay, More Discussion of SEC Rule Proposals on Noisy Withdrawal,” 34 Sec. Reg. \& L. Rep. (BNA) 2045 (2002); 
Pacelle and Schroeder, "Proposed SEC Rules Could Turn Lawyers Into WhistleBlowers," Wall St. J., Jan. 9, 2003, at p. A1.

70. See, e.g., "Thirty Prominent Securities Lawyers Tell SEC Reporting Proposal Threatens Public Firms,” 34 Sec. Reg. \& L. Rep. (BNA) 1947 (2002).

71. Id. at 1947 (asserting that the proposed rule "would impair [the] ability to render independent legal advice").

72. See Comment Letter to the SEC from Professors Susan P. Koniak, Roger C. Cramton and George M. Cohen (December 2002).

73. ABA Comm. on Ethics and Prof'1 Responsibility, Formal Op. 92-366 (1992) (setting forth the limited instances in which an attorney may "disaffirm documents prepared in the course of the representation that are being, or will be, used in furtherance of [a] fraud, even though such a 'noisy' withdrawal may have the collateral effect of inferentially revealing client confidences").

74. Id. A number of state ethical rules mandate that counsel make a noisy withdrawal under specified circumstances. For example, the Tennessee Rules of Professional Conduct provide in Rule 1.4(b), (c):

(b) If, in the course of representing a client in a non-adjudicative matter, a lawyer knows that the client intends to perpetrate a crime or fraud, the lawyer shall promptly advise the client to refrain from doing so and shall consult with the client about the consequences of the client's conduct. If 
after such consultation, the lawyer knows that the client still intends to engage in the wrongful conduct, the lawyer shall:

(1) Withdraw from the representation of the client in the matter; and

(2) Give notice of the withdrawal to any person who the lawyer knows is aware of the lawyer's representation of the client in the matter and whose financial or property interests are likely to be injured by the client's criminal or fraudulent conduct. The lawyer shall also give notice to any such person of the lawyer's disaffirmance of any written statements, opinions, or other material prepared by the lawyer on behalf of the client and which the lawyer reasonably believes may be used by the client in furtherance of the crime or fraud.

(c) If a lawyer who is representing or has represented a client in a non-adjudicative matter comes to know, prior to the conclusion of the matter, that the client has, during the course of the lawyer's representation of the client, perpetrated a crime or fraud, the lawyer shall promptly advise the client to rectify the crime or fraud and consult with the client about the consequences of the client's failure to do so. If the client refuses or is 
unable to rectify the crime or fraud, the lawyer shall:

(1) If currently representing the client in the matter, withdraw from the representation and give notice of the withdrawal to any person whom the lawyer knows is aware of the lawyer's representation of the client in the matter and whose financial or property interests are likely to be injured by the client's criminal or fraudulent conduct; and

(2) Give notice to any such person of the lawyer's disaffirmance of any written statements, opinions, or other material prepared by the lawyer on behalf of the client and that the lawyer reasonably believes may be used by the client in furtherance of the crime or fraud.

75. See ABA, Model Rules of Professional Conduct, rule 1.2 comment 10 (stating that "[i]n some circumstances, withdrawal alone might be insufficient" and that "[i]t may be necessary for the lawyer to give notice of the fact of withdrawal and to disaffirm any opinion, document, affirmation or the like"); id. rule 4.1 comment 3 (stating that [s]ometimes it may be necessary for the lawyer to give notice of the fact of withdrawal and to disaffirm an opinion, document, affirmation or the like"). See also, NY Code of Prof. Resp. DR 4-101(c)(5) (setting forth that a "lawyer may 
reveal ... [c]onfidences or secrets to the extent implicit in withdrawing a written or oral opinion or representation previously given by the lawyer and believed by the lawyer still to be relied upon by a third person where the lawyer has discovered that the opinion or representation was based on materially inaccurate information or is being used to further a crime or fraud"); Tenn. Rules of Professional Conduct, rule 1.4(b), (c) (requiring noisy withdrawal, discussed supra note 74). 76. Compare Ganino v. Citizens Utilities Co., 228 F.3d 154 ( $2^{\text {nd }}$ Cir. 2000), with Parnes v. Gateway 2000, Inc., 122 F.3d $539\left(8^{\text {th }}\right.$ Cir. 1997). See also, SEC Staff Accounting Bulletin 99, 64 Fed. Reg. 45,150 (Aug. 19, 1999). See generally Hodges, "The Qualitative Considerations of Materiality: The Emerging Relationship Between Materiality and Scienter," 30 Sec. Reg. L.J. 4 (2002). 77. See Schwartz, "Lawyer Rules Go Too Far,” Nat. L.J., Dec. 16, 2002, at p. A13.

78. See "ABA Panelists Assess How Sarbanes-Oxley SEC Rules Will Change Practice and Ethics," 35 Sec. Reg. \& L. Rep. (BNA) 312 (2003) (quoting SEC Chief Litigation Counsel David Kornblau that "obtain[ing] an opinion from outside counsel" would be advisable in certain circumstances). Such a second opinion should focus on whether the reporting lawyer's belief regarding evidence of a material violation is reasonably likely to be valid. But see infra note 80 . 
79. See ABA, Model Rules of Professional Conduct, rule 1.13(b); N.Y. Code of Professional Responsibility, DR 5-109(b)(2); Texas Disciplinary Rules of Professional Conduct, rule 1.12(c)(2).

80. See Implementation of Standards of Professional Conduct for Attorneys, Securities Exchange Act Release No. 47276, [2002-2003 Transfer Binder] CCH Fed. Sec. L. Rep. ๆ 86,823, at pp. 87,105-87,108 (2003) (codified at 17 C.F.R. $\S \S$ 205.2(b), 205.3(b)(6)(ii). At this time, the SEC employs the term "colorable defense" in this context. Such a vague and weak standard would seem to be counterproductive. As stated by one source:

The existence of a colorable defense allows a lawyer-advocate once a client's conduct is challenged in a forum as unlawful, to argue that the conduct, even if very likely illegal, is legal. It has no other relevance. The colorable defense standard certainly should not be used to permit lawyers to advise clients, particularly corporate clients with fiduciary obligations to their owner-shareholders, to proceed with conduct that is very likely illegal. But that is precisely what could happen. The rule as adopted suggests that one alternative to stopping an ongoing fraud or abandoning plans to commit a new fraud is to get an opinion from a lawyer that should the issuer be investigated for the illegal conduct (there is no requirement in the definition 
that the investigation be underway, pending or even likely to occur), a colorable defense would be available. The SEC should not be suggesting to anyone that the fact that a lawyer can (in good faith and/or reasonably) state that a "colorable defense" would be available, if the action is ever challenged, licenses an issuer to engage in activity that may more likely than not be illegal.

Cramton, Cohen and Koniak, supra note 61, at 771.

81. As this author opined over twenty years ago:

$[\mathrm{T}]$ he second opinion is not recommended as a 'sure-proof' mechanism. Its greatest attribute, however, is its precautionary deliberative nature. For clients who desire to procure such an opinion, it may well work to their ultimate benefit. For lawyers, the second opinion may lower the risks of successful malpractice claims and may even lower the costs of malpractice insurance premiums.

Sporkin and Steinberg, "Second Opinion for Lawyers - The 'Consultative Attorney,' N.Y.L.J., Jan. 3, 1983, at pp. 1, 3. See Editorial, “A Second Opinion,” Nat. L.J., Jan. 10, 1983, at p. 12 ("We agree with Mr. Sporkin and Mr. Steinberg that the concept is a good one, and that attorneys should be open to its use in the future.”). 
82. See Hooker, "Lawyers' Responses to Audit Inquiries and the Attorney-Client Privilege," 35 Bus. Law. 1021 (1980). The discussion contained in this Section derives derives from Steinberg, "Attorney Liability for Client Fraud,” 1991 Colum. Bus. L. Rev. 1, 22-25 (1991). With respect to overseeing the quality control, ethical and auditing standards of accounting firms that audit publicly-held companies, the Sarbanes-Oxley Act (SOX) established the Public Company Accounting Oversight Board (PCAOB). See SOX $\S 101$. The duties of the PCAOB, as set forth in the statute, are to:

(1) register public accounting firms that prepare audit reports for issuers, in accordance with [SOX] section 102;

(2) establish or adopt, or both, by rule, auditing, quality control, ethics, independence, and other standards relating to the preparation of audit reports for issuers, in accordance with [SOX] section 103;

(3) conduct inspections of registered public accounting firms, in accordance with [SOX] section 104 and the rules of the Board;

(4) conduct investigations and disciplinary proceedings concerning, and impose appropriate sanctions where justified upon, registered public accounting firms and associated persons of such firms, in accordance with [SOX] section 105; 
(5) perform such other duties or functions as the Board (or the Commission, by rule or order) determines are necessary or appropriate to promote high professional standards among, and improve the quality of audit services offered by, registered public accounting firms and associated persons thereof, or otherwise to carry out this Act, in order to protect investors, or to further the public interest;

(6) enforce compliance with this Act, the rules of the Board, professional standards, and the securities laws relating to the preparation and issuance of audit reports and the obligations and liabilities of accountants with respect thereto, by registered public accounting firms and associated persons thereof; and

(7) set the budget and manage the operations of the Board and the staff of the Board.

Id. $\S 101(\mathrm{c})$.

83. For a review of "contingent liabilities" in the audit request setting, see American Bar Association, “Statement of Policy Regarding Lawyers' Responses to Auditors' Requests for Information,” 31 Bus. Law. 1709, 1712 (1976) (ABA Policy Standard).

84. See C. Wolfram. Modern Legal Ethics 677 (1986). 
85. For an analysis of the attorney-client and work product privileges in the audit inquiry setting, see Hooker, supra note 82 , at 1021-1034. The ABA

Subcommittee on Audit Inquiry Responses set forth model language for client request letters and attorney response letters which attempts to preserve the privileges from waiver. See Subcommittee on Audit Inquiry Responses, "Inquiry of a Client's Lawyer Concerning Litigation, Claims, and Assessments: Auditing Interpretation AU Section 337," 45 Bus. Law. 2245 (1990). See also, Fuld, “Lawyers' Responses to Auditors - Some Practical Aspects," 44 Bus. Law. 159 (1988).

86. See ABA Policy Statement, supra note 83, at 10 (providing a more detailed discussion of the competing policy considerations).

87. In addition, a failure to disclose material facts may be viewed by the auditor "as a limitation on the scope of the audit, necessitating a disclaimer of opinion or, depending on the circumstances, other qualification, which could render the financial statements effectively unaudited." Lorne, "The Corporate and Securities Advisor, the Public Interest, and Professional Ethics," 76 Mich. L. Rev. 425, 448 (1978). See Securities Act Release No. 4458 (1962) (“A ‘subject to’ or 'exempt for' opinion paragraph in which those phrases refer to the scope of the audit ... is not acceptable in certificates filed with the Commission in connection with the 
public offering of securities.”).

88. See Section 303(a) of the Sarbanes-Oxley Act:

It shall be unlawful, in contravention of such rules or regulations as the Commission shall prescribe as necessary or appropriate in the public interest or for the protection of investors, for any officer or director of an issuer, or any other person acting under the direction thereof, to take any action to fraudulently influence, coerce, manipulate, or mislead any independent public or certified accountant engaged in the performance of an audit of the financial statements of that issuer for the purpose of rendering such financial statements materially misleading.

Implementing this directive, Rule 13b2-2(b)(1) provides:

No officer or director of an issuer, or any other person acting under the direction thereof, shall directly or indirectly take any action to coerce, manipulate, mislead, or fraudulently influence any independent public or certified public accountant engaged in the performance of an audit or review of the financial statements of that issuer that are required to be filed with the Commission pursuant to this subpart or otherwise if that person knew or should have known that such action, if successful, could result in rendering the issuer's financial statements materially misleading. 
89. Securities Exchange Act Release No. 47890, [2003 Transfer Binder] CCH

Fed. Sec. L. Rep. ๆ 86,921, at p. 87,661 (2003). See Winer and Seabolt, "Responding to Audit Inquiries in a Time of Heightened Peril," 36 Sec. Reg. \& L. Rep. (BNA) 1902 (2004). See also, Hinsey, "Communications Among Attorneys, Management and Auditors," 36 Bus. Law. 727 (1981).

90. ABA Policy Statement, supra note 83, at 1712.

91. Id. at 1712. See Tew v. Arky, Freed, Stearns, Watson, Greer, Weaver \& Harris, 655 F. Supp. 1573 (S.D. Fla. 1987) (holding that law firm had no disclosure duty to its client's auditor where client did not identify its financial difficulties in the auditor's inquiry letter and did not request the law firm to comment in regard thereto).

92. ABA Policy Statement, supra note 83, at 1713. According to the ABA Policy Statement, "an unfavorable outcome for the client is probable if the prospects of the claimant not succeeding are judged to be extremely doubtful and the prospects for success by the client in its defense are judged to be slight." Id. On the other hand, "an unfavorable outcome is remote if the prospects for the client not succeeding in its defense are judged to be extremely doubtful and the prospects of success by the claimant are judged to be slight." Id. 93. Id. at 1714 .

94. See Wolfram, supra note 84, at 678; Frank, "A Higher Duty: A New Look at $-70-$ 
the Ethics of the Corporate Lawyer," 26 Clev. St. L. Rev. 337, 356 (1977).

95. See supra notes 88-89 and accompanying text.

96. See sources cited supra note 3.

97. See Watson, "Relationships with Auditors: Heightened Tensions and Their

Impact on the Audit Response Process," Securities Regulation and Business Law

Problems, University of Texas Law School (2005). See also, Winer and Seabolt, supra note 89, at 1905 (stating that "[a]ttorneys should refrain from representing that they cannot form an opinion on the likely outcome of litigation").

98. 13 Bankr. R. 54, 4 Collier Bankr. Cas. 2d 913, 7 Bankr. Ct. Dec. 1031, Bankr.

L. Rep. ๆ 68,073, 8 Fed. R. Evid. Serv. 938 (Bkrtcy, S.D.N.Y., June 10, 1981) (No.

81 B 10533) et seq. See Steinberg, supra note 82, at 21-22.

99. See Sonde and Bierman, "O.P.M. Forces Counsel to Ponder Limits of

Disclosure," Legal Times, Feb. 7, 1983, at p. 14. For discussion on the O.P.M. matter, see Comment, "The Client-Fraud Dilemma: A Need for Consensus," 46

Md. L. Rev. 436 (1987).

100. Unfortunately, sending "red flags" would be difficult if the successor counsel is unaware of the predecessor counsel's representation and resignation. 101. See Brown, "Counsel With a Fraudulent Client," 17 Rev. Sec. Reg. 909, 913 (1984).

102. With respect to prospective successor counsel making inquiry of predecessor 
counsel, see the National Student Marketing Corp. settlement. In that case, one of the law firms that settled with the SEC agreed to the implementation of the following procedures:

Prior to the undertaking by the Firm of corporate representation as principal outside counsel of a prospective client having securities registered under the Federal Securities Laws ... if the Firm has ascertained that the representation of such prospective client by its prior principal outside counsel was terminated by such counsel, due inquiry will be made of such prospective client as to the reasons for the change and the prospective client will be requested to release such prior counsel from any obligation of confidentiality for purposes of discussion with the Firm of the proposed representation. Appropriate documentation reflecting the results of any such inquiry will be maintained by the Firm and will be available on a continuing basis to lawyers actively participating in the Firm's representation of the client.

SEC v. National Student Marketing Corp., [1977-1978 Transfer Binder] CCH Fed.

Sec. L. Rep. ๆ 96,027, at p. 91,599 (D.D.C. 1977).

103. As the Commission stated twenty-five years ago:

We do not imply that a lawyer is obliged ... to seek to correct every 
isolated disclosure action or inaction which he believes to be at variance with applicable disclosure standards, although there may be isolated disclosure failures that are so serious that their correction becomes a matter of primary professional concern. It is also clear, however, that a lawyer is not privileged to unthinkingly permit himself to be co-opted into an ongoing fraud and cast as a dupe or a shield for a wrong-doing client.

Initially, counseling accurate disclosure is sufficient, even if his advice is not accepted. However, there comes a point at which a reasonable lawyer must conclude that his advice is not being followed, or even sought in good faith, and that his client is involved in a continuing course of violating the securities laws. At this critical juncture, the lawyer must take further, more affirmative steps in order to avoid the inference that he has been co-opted, willingly or unwillingly, into the scheme of nondisclosure.

The lawyer is in the best position to choose his next step.

Resignation is one option, although we recognize that other considerations, including the protection of the client against foreseeable prejudice, must be taken into account in the case of withdrawal. A direct approach to the board of directors or one or more individual directors or officers may be appropriate; or he may choose to try and enlist the aid of other members of 
the firm's management. What is required, in short, is some prompt action that leads to the conclusion that the lawyer is engaged in efforts to correct the underlying problem, rather than having capitulated to the desires of a strong-willed, but misguided [constituent of a] client.

Some have argued that resignation is the only permissible course when a client chooses not to comply with disclosure advice. We do not agree. Premature resignation serves neither the end of an effective lawyerclient relationship nor, in most cases, the effective administration of the securities laws. The lawyer's continued interaction with his client will ordinarily hold the greatest promise of corrective action. So long as a lawyer is acting in good faith and exerting reasonable efforts to prevent violations of the law by his client, his professional obligations have been met. In general, the best result is that which promotes the continued, strongminded and independent participation by the lawyer.

We recognize, however, that the 'best result' is not always obtainable, and that there may occur situations where the lawyer must conclude that the misconduct is so extreme or irretrievable, or the involvement of his client's management and board of directors in the misconduct is so thorough-going and pervasive that any action short of 
resignation would be futile. We would anticipate that cases where a lawyer has no choice but to resign would be rare and of an egregious nature. In re Carter and Johnson, [1981 Transfer Binder] CCH Fed. Sec. L. Rep. ๆ 82,847, at pp. $84,172-84,173(1981)$.

104. See discussion supra notes 65-75 and accompanying text.

105. See, e.g., SEC v. Sargent, 229 F.3d 68, $75\left(1^{\text {st }}\right.$ Cir. 2000) (stating that "circumstantial evidence, if it meets all the other criteria of admissibility, is just as appropriate as direct evidence").

106. See ABA Comm. on Ethics and Prof. Responsibility, Formal Op. 00-418 (2000) (stating that attorneys who enter these fee arrangements "inform the client that events following the stock acquisition could create a conflict between the lawyer's exercise of her independent professional judgment as a lawyer on behalf of the corporation and her desire to protect the value of her stock," and that "[t]he best way to comply with the requirements of Rule 1.8(a) is to set forth the salient terms of the transaction in a document written in a language that the client can understand and, after the client has had an opportunity to consult with independent counsel, to have the document signed by both client and lawyer"). See also, Formal Opinion 2003-3 of the Association of the Bar of the City of New York, Committee on Professional and Judicial Ethics (2000). See generally Steinberg, 
supra note 1, at $\S 11.04$; Klein, "No Fool for a Client: The Finance and Incentives Behind Stock-Based Compensation for Corporate Attorneys," 1999 Colum. Bus.

L. Rev. 329 (1999); McAlpine, "Getting a Piece of the Action: Should Lawyers Be Allowed to Invest in Their Clients' Stock?," 47 UCLA L. Rev. 549 (1999); Puri, “Taking Stock of Taking Stock," 87 Cornell L. Rev. 99 (2001). 